\title{
Blood Lead Levels in Children Living Close to the Antimony and Lead Mining-milling-smelting Complex in Serbia
}

\author{
BRANISLAVA I. MATIĆ, Institute of Public Health of Serbia \\ „Dr Milan Jovanović Batut“, Belgrade
SNEŽANA M. DEJANOVIĆ, Institute of Public Health of Serbia \\ Original scientific paper \\ UDC: $614.878-053.2$ \\ „Dr Milan Jovanović Batut“, Belgrade
NELA Ž. ĐONOVIĆ, University of Kragujevac, \\ $612.014 .46-053.2$ \\ 615-099:546.815
}

Faculty of Medical Sciences, Department of Hygiene and Ecology, Kragujevac

\begin{abstract}
Objective of this cross-sectional study was to determine blood lead concentrations in children, living in the vicinity of the Zajača lead-antimony mining-milling-smelting complex. Other aims were to compare blood lead levels (BLLs) of exposed children to those of partially exposed and non-exposed, and correlate values of BLLs from two consecutive sampling series in 2012 and 2013. Performed laboratory method was atomic absorption spectrometry (AAS). Statistical significance of comparisons was tested by univariate methods and non-parametric tests for the attributable variables: Hi-square test, proportion test. In the case of non-parametric variables, following tests were used: Kolmogorov-Smirnov Z test for testing distribution's normality; ANOVA for the normal distribution, while a Kruskal Wallis Test was used in cases without normal distribution. 142 participants were tested on lead in blood: exposed, partially exposed, and non-exposed). Mean BLLs in children living at less than $1 \mathrm{~km}$ from the smelter was $18.98 \mu \mathrm{g} / \mathrm{dl}$, at first test series, and $12.21 \mu \mathrm{g} / \mathrm{dl}$, in the second round. For those living further than $3 \mathrm{~km}$ mean BLLs at first series was 8.30, and at the second series it was 5.85). Blood lead concentrations in children from Zajača are highest.
\end{abstract}

Key words: blood lead levels, lead exposed children, lead smelter

\section{INTRODUCTION}

Lead is a ubiquitous environmental contaminant and as such is of worldwide public health concern $[1,2]$. The adverse chronic health effects of long-term low-level exposure to lead $(\mathrm{Pb})$ include hematological and both central and peripheral neurological functions impairment [3, 4]. For some naturally occurring reasons children represent the population of highest risk from lead exposure. Reason for this are lifestyle habits and behavior of children, the fact that food intake per unit body weight is higher than in adults, [5]. Children practice particular behavioral habits (such as pica), their metabolism and ventilation rates are higher than in adults, and compared with the adult population children absorb almost $50 \%$ of ingested $\mathrm{Pb}$, while the

Author's address: Branislava Matić, Institute of Public Health of Serbia, „Dr Milan Jovanović Batut“, Belgrade, Dr Subotića starijeg 5

e-mail: damjanko98@yahoo.com

Paper received: 07.05.2018.

Paper accepted: 15.05.2018. adults only $10 \%$ [6-9]. In a number of countries, results have been published from the surveys of biological monitoring of children's BLLs [10-13]. Some relevant investigations have, also, been carried out in children living around point-sources of lead pollution [14-16].

Mining and mineral processing has played a vital part in the history and economy of the Western Balkans [17, 18, 19]. Naturally, environmental hotspots in Serbia are, principally, associated with mining, processing and smelting of mentioned metal ores.

The highest lead contamination in Serbia occurs in Zajača, a remote village of the Loznica Municipality, western Serbia, $140 \mathrm{~km}$ from the capital city of Belgrade. The village counts 600 inhabitants living in 225 dwellings. It is located close to Serbia's natural border with Bosnia and Herzegovina, the Drina River, making it a source of transboundary pollution [20].

\section{Background information}

Antimony ( $\mathrm{Sb}$ ) mine in Zajača was opened in 1873 , to be followed with a smelter on the site, in 1877 , producing $126 \mathrm{t}$ of antimony during the first year of 
operation. The capacity has increased to $8 \mathrm{t}$ of antimony per 24 hours during 1938 [17]. Annual production was approximately $2000 \mathrm{t}$ in the period between 1950 and 1980, with a maximum annual production of $2768 \mathrm{t}$, achieved in 1965 [18]. After 1980, the antimony production has declined to $1000-2000 \mathrm{t}$ per year, to be finally terminated in 1990 .

Due to low market price of antimony, and low quality of available ore, especially due to high arsenic content [19]. About 84000 t of antimony regularly has been produced in "Zajača" during its existence, from 1877-1990 [16].

Today, refined lead from secondary raw materials (batteries) and lead-antimony alloys with the total volume of production of about $25000 \mathrm{t}$ per year, is being produced in "Zajača".

Defined environmental health hazards in Zajača are: toxic solid waste, airborne toxic and sulphuric, toxic/acidic effluents, uncontained waste rock, dust emissions and unsecured workings, poorly contained and unstable tailing wastes, poorly contained smelter residues and chemicals [19]. The plant generates wastewater of high metal contents, with no pre-treatment.

As for the drinking water sources, homes are still not connected to the central drinking water distribution network, leaving inhabitants to the only underground water supply source, whose water runs bellow the historical tailings, so a whole series of heavy metals could be detected in the water.

Air pollution generates from industrial emissions to ambient air from the smelting process. Industrial waste water disposal runs freely into the River Štira (part of the Drina River Basin).

Until recently, little was known or done about lead exposure and its associated health risks in Serbia itself, being of particular concern in areas close to the mining-milling-smelting complex.

Key objective of this cross-sectional study was to determine blood lead levels (BLLs) in children living in an area contaminated by the secondary lead smelter, in Zajača. Another aim was to determine the level of statistical significance in correlating BLLs of exposed children in blood samples taken in two consecutive blood sampling procedures, the first one taking place in 2012 and the other in 2013, giving a certain period for the preventive measures to show any results at the second sampling.

By taking into account the data concerning their home address, included in the standardized questionnaire, we aimed to determine the level of statistical significance between their home/school address and blood lead concentration in samples taken from them.

\section{METHODS AND DATA COLLECTION}

This study included 142 individuals, of which 68 were female and 74 male. Total number of exposed individuals from Zajača was 74, of which, 58 were children, and 16 parents working in the plant. Samples were, also, taken from 38 partially exposed Paskovac children, and 30 from the non-exposed group living in Gornja Borina.

Groups were formed according to the home address, i.e. its distance from the point source of pollution, and named as exposed, partially exposed and nonexposed. The first group, consisting strictly of Zajača inhabitants (exposed), included 74 children, and 16 parents employed at the plant ( $\mathrm{N}=90)$; the second group consisted of 38 children living in the neighbouring village Paskovac (partially exposed). Parents were not interested in sampling children from Gornja Borina for the first sampling series in 2012, but letting 30 of them to be tested for BLL in the second series in 2013.

As seen in Figure 1, group of exposed children lives in Zajača, partially exposed in the neighbouring Paskovac, and non-exposed ones in the furthest, hilly village of Gornja Borina. Before this series of testing, a research has been performed in 1999, with the same aim. In both studies we used the same form of a standardized questionnaire. When compared with the tests being of our concern in this paper, a strong similarity is shown in BLLs among them [20]. Knowing this fact, our final aim was to confirm presence of continuous public health risks, due to persistent environmental contamination by the same point-source of pollution, for decades.

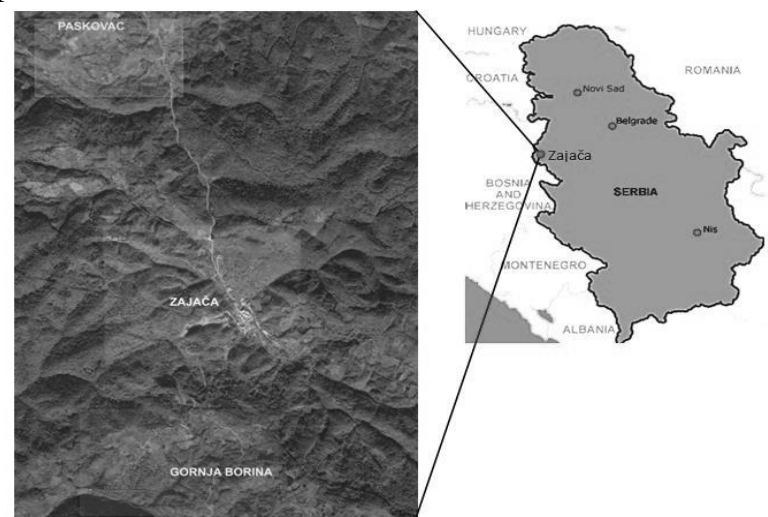

Figure 1 - Location of Zajača,Paskovac and Gornja Borina

First of the new series of blood sampling in children has been performed in 2012, voluntarily. Blood samples were taken by the staff of the National Institute of Occupational Health in Belgrade, and then transported to the referent toxicological laboratory of the same institution.

The same lab took the samples in 2013 , and has sent ten percent of them (15 samples) to the reference 
laboratory in the Institute "Stephan Josef", in Ljubljana, Slovenia, for inter-laboratory verification, showing the matching of received values at both laboratories. Blood was tested on the presence of lead by atomic absorption spectroscopy. Actually, some of their elder siblings have been participating in a latter study when blood lead concentrations have shown significant level of exposure [20].

Simultaneously, Serbian Environmental Agency (SEPA) has installed an automatic measuring station (AMS) for ambient air quality monitoring, next to the lead processing plant. This particular AMS is a part of the National network of AMSs established in 2010, and approved by the Parliament, whose measuring results could be followed on-line at the SEPA website, in real time [21].

Local Institute of Public Health in Šabac has also measured ambient air quality, groundwater quality, and industrial wastewater effluents. This paper also aims to prove existence of long-term exposure of local children to lead, although, the plant works with reduced capacity for almost a year, with particles of lead scattered throughout all environmental fractions.

A Working Group was formed by the Ministry of Health of Serbia (in which authors participated), and an Action Plan defined, upon which the activities were conducted.

\section{Statistical methodology}

For testing statistical significance for the difference of the variables, we used univariate methods, together with the non-parametric tests for the attributable variables: Hi-square test, proportion test. In the case of testing significance of the difference among non-parametric variables, the following tests were used: Kolmogorov-Smirnov $\mathrm{Z}$ test for testing distribution's normality; ANOVA for the normal distribution, while a Kruskal Wallis Test was used in cases without normal distribution.

\section{RESULTS}

Serbian Environmental Agency (SEPA) has installed an automatic measuring station (AMS) for ambient air quality monitoring, next to the lead processing plant, in 2012, when the public uproar on the exposure of children to lead has started (Table 1). This station works continuously and the measuring results could be found in real-time, at the SEPA website. Contrary to the expectations, results showed that lead is not a dominant public health risk at the incriminated location, but cadmium and arsenic, primarily, meaning that any future research should cope with overall heavy metal presence in the environment due to a complex longterm pollution of this metal-processing site.

Table 1. Ambient air quality sampled for the presence of heavy metals (2012) by SEPA*

\begin{tabular}{|l|l|l|l|l|l|}
\hline \multirow{2}{*}{$\begin{array}{l}\text { Limit values (annual } \\
\text { mean) [25] }\end{array}$} & $\mathbf{P b}\left(\mu \mathrm{g} / \mathrm{m}^{3}\right)$ & $\mathbf{C d}\left(\mathrm{ng} / \mathrm{m}^{3}\right)$ & $\mathbf{N i}\left(\mathrm{ng} / \mathrm{m}^{3}\right)$ & $\mathbf{A s}\left(\mathrm{ng} / \mathrm{m}^{3}\right)$ & $\mathbf{P M 1 0}\left(\mu \mathrm{g} / \mathrm{m}^{3}\right)$ \\
\cline { 2 - 6 } & 0.5 & 5.0 & 20.0 & 6.0 & 50 \\
\hline Mean & 0.48 & $\mathbf{2 7 . 1 5}$ & 3.66 & 6.5 & 29.66 \\
\hline Maximum & 2.3 & $\mathbf{3 1 3 . 2}$ & 18.1 & $\mathbf{3 8 . 8}$ & $\mathbf{5 7 . 4 9}$ \\
\hline
\end{tabular}

*SEPA - Serbian Environment Protection Agency

Although the performed measuring does not show has decided to provide its continuity, as shown in significant increase of lead in ambient air, government Figure 2.

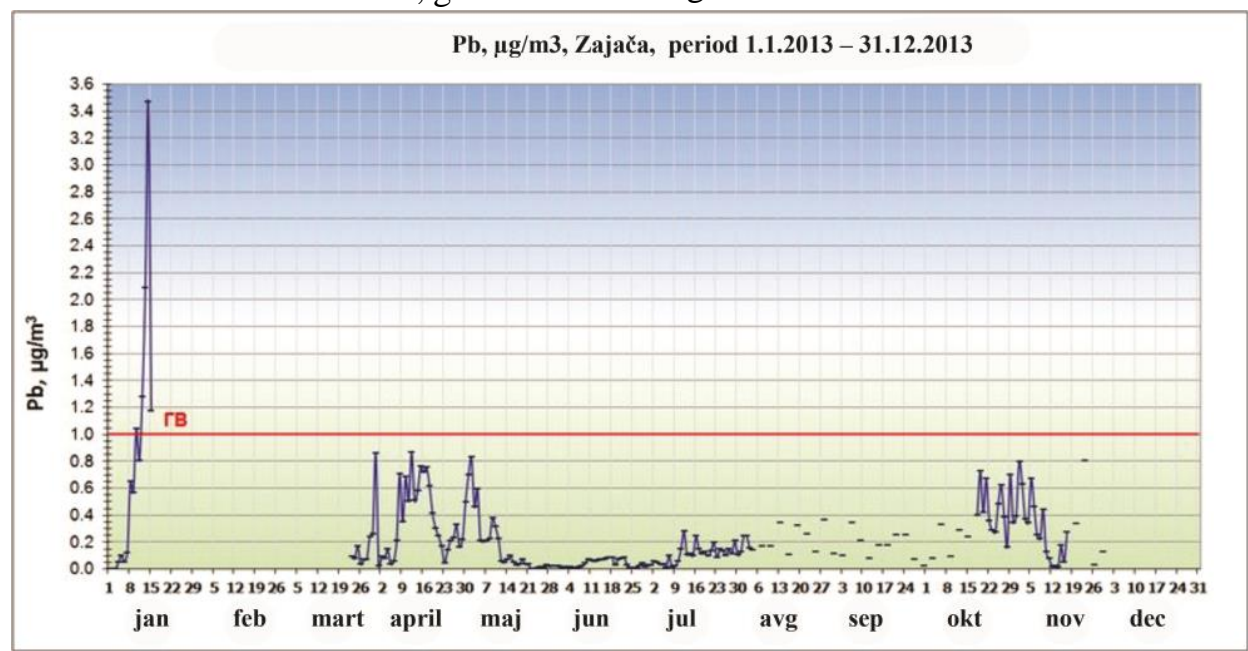

Figure 2 - Monitoring of PM10 lead contents in 2013 in the vicinity of the smelter [22]

In testing the normality of the distribution in BLL 2013, a statistically significant difference has been series taken in two consecutive samplings in 2012 and proven among groups, when correlating them, 
according to the location i.e. exposure level (Kolmogorov-Smirnov Z, p < 0,000), as exposed and partially exposed individuals. In further statistical analysis a significant decrease in BLL has been shown when correlating the second sampling series with the first one, also for both the exposed (Kruskal Wallis Test=25.16, $\mathrm{df}=1, \mathrm{p}<0.0001$ ), and partially exposed population group (Kruskal Wallis Test=36.75, df $=1, \mathrm{p}<0.0001$ ). At the first sampling series more prevalent were children from the exposed group with BLL of higher values. For example, among exposed children, samples with concentration ranging from 15.00-19.99 $\mu \mathrm{g} / \mathrm{dl}$ belonged to 12 of them $(22.6 \%)$, while, among the partially exposed children, only 1 sample $(4,5 \%)$ fell into this range interval of $15-19.99 \mu \mathrm{g} / \mathrm{dl}$.

On the other hand, among those samples with BLLs ranging from $10-14,99 \mu \mathrm{g} / \mathrm{dl}$, there were 12 samples $(54.5 \%)$ among partially exposed (Paskovac), and 16 samples of the exposed individuals from Zajača $(30,2 \%)$, with a highly significant statistical difference of $\chi 2=26.612, p<0.0001$. In the second blood lead testing series, more prevalent were the exposed subjects (Zajaca) having higher BLL values, with 23 $(31,1 \%)$ samples ranging $10-14,99 \mu \mathrm{g} / \mathrm{dl}$, while among the partialy exposed children from Paskovac, only 2 $(5,3 \%)$ of their samples had blood $\mathrm{Pb}$ values in the same range category. Talking of a higher BLL value range $(15-19,99 \mu \mathrm{g} / \mathrm{dl})$, there was only 1 child in the partially exposed group (5,3\%), and $11(14,9 \%)$ in the group of exposed children in Zajaca, which is a significantly smaller number of both exposed and partially exposed children having blood lead concentration belonging to the lower range of $10-14,99 \mu \mathrm{g} / \mathrm{dl} \quad(\chi 2=23.991$, $\mathrm{p}<0.0001)$.

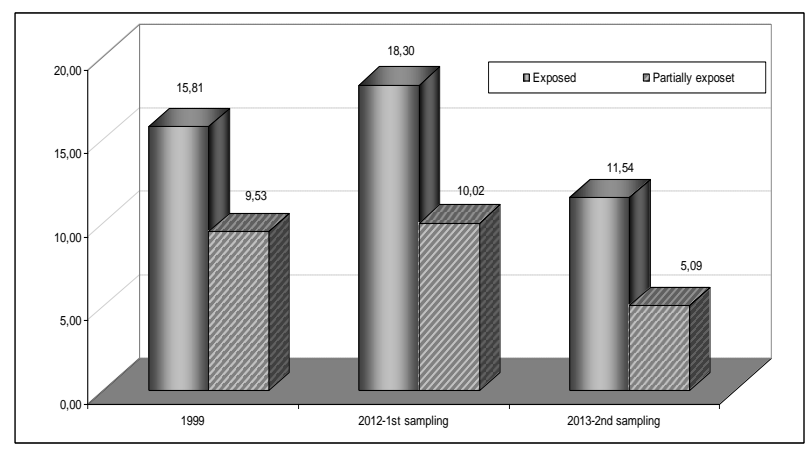

Figure 3 - Mean BLLs in tests according to the home address i.e. exposure level

At the second series of blood sampling in children living in Zajača (exposed) an increase of the number of samples with BLLs below $10 \mu \mathrm{g} / \mathrm{dl}$ has occured, changing status from $5,7 \%$ to $44,6 \%$ i.e 7,5 - fold. In samples taken from partially exposed children of Paskovac, an increase in the number of samples measuring below $10 \mu \mathrm{g} / \mathrm{dl}$ changed from $4.0, \%$ to $92.1 \%$.

Further analysis of both sampling groups (first sampling in 2012; second sampling in 2013) proved that statistically significant higher number of samples from the second testing had BLLs below $10 \mu \mathrm{g} / \mathrm{dl}$, in comparison with the samples from the first testing period, in totally exposed $(\mathrm{p}<0.01)$ and partially exposed $(\mathrm{p}<0.001)$ population groups.

Table 2. Groups according to BPb concentration range at $1^{\text {st }}$ and $2^{\text {nd }}$ tests in Zajaca and Paskovac

\begin{tabular}{|c|c|c|c|c|c|c|c|c|}
\hline \multirow{8}{*}{$\begin{array}{l}\text { Groups } \\
\text { according } \\
\text { to BLLs at } \\
1^{\text {st }} \text { test } \\
(2012)\end{array}$} & \multirow{2}{*}{$\mu \mathrm{g} / \mathrm{dl}$} & \multicolumn{2}{|c|}{ Exposed } & \multicolumn{2}{|c|}{ Partially exposed } & \multirow{2}{*}{ Total } & \multirow{2}{*}{$\%$} & \multirow{2}{*}{ Chi.Sig. } \\
\hline & & $\mathrm{N}$ & $\%$ & $\mathrm{~N}$ & $\%$ & & & \\
\hline & $<10$ & 3 & 5.7 & 9 & 40.9 & 12 & 16.0 & \multirow{2}{*}{26.612} \\
\hline & $10-14.99$ & 16 & 30.2 & 12 & 54.5 & 28 & 37.3 & \\
\hline & $15-19.99$ & 12 & 22.6 & 1 & 4.5 & 13 & 17.3 & \multirow{2}{*}{$\mathrm{df}=5$} \\
\hline & $20-24.99$ & 16 & 30.2 & 0 & 0.0 & 16 & 21.3 & \\
\hline & $25-29.99$ & 3 & 5.7 & 0 & 0.0 & 3 & 4.0 & \multirow{3}{*}{$0.0001 * * *$} \\
\hline & $30-34.99$ & 3 & 5.7 & 0 & 0.0 & 3 & 4.0 & \\
\hline \multicolumn{2}{|l|}{ Total } & 53 & 70.7 & 22 & 29.3 & 75 & 100.0 & \\
\hline \multirow{9}{*}{$\begin{array}{l}\text { Groups } \\
\text { according } \\
\text { to BLLs at } \\
2^{\text {nd }} \text { test } \\
(2013)\end{array}$} & \multirow{2}{*}{$\mu \mathrm{g} / \mathrm{dl}$} & \multicolumn{2}{|c|}{ Exposed } & \multicolumn{2}{|c|}{ Partially exposed } & \multirow{2}{*}{ Total } & \multirow{2}{*}{$\%$} & \multirow{2}{*}{ Chi.Sig. } \\
\hline & & $\mathrm{N}$ & $\%$ & $\mathrm{~N}$ & $\%$ & & & \\
\hline & $<10$ & 33 & 44.6 & 35 & 92.1 & 68 & 60.7 & \multirow{3}{*}{23.991} \\
\hline & $10-14.99$ & 23 & 31.1 & 2 & 5.3 & 25 & 22.3 & \\
\hline & $15-19.99$ & 11 & 14.9 & 1 & 2.6 & 12 & 10.7 & \\
\hline & $20-24.99$ & 4 & 5.4 & 0 & 0.0 & 4 & 3.6 & \multirow{2}{*}{$\mathrm{df}=5$} \\
\hline & $25-29.99$ & 2 & 2.7 & 0 & 0.0 & 2 & 1.8 & \\
\hline & $30-34.99$ & 1 & 1.4 & 0 & 0.0 & 1 & 0.9 & \\
\hline & $40+$ & 0 & 0.0 & 0 & 0.0 & 0 & 0.0 & $0.0001 * * *$ \\
\hline Total & & 74 & 66.1 & 38 & 33.9 & 112 & 100 & \\
\hline
\end{tabular}


When targeting blood samples with BLL below 20 $\mu \mathrm{g} / \mathrm{dl}$, a statistically significant number of samples taken in the second testing falls into this group, compared to those from the first testing, for a totally exposed population group $(\mathrm{p}<0.001)$, while for the partially exposed group at both sampling episodes, all samples had BLL concentration below $20 \mu \mathrm{g} / \mathrm{dl}$ (Figure 4).

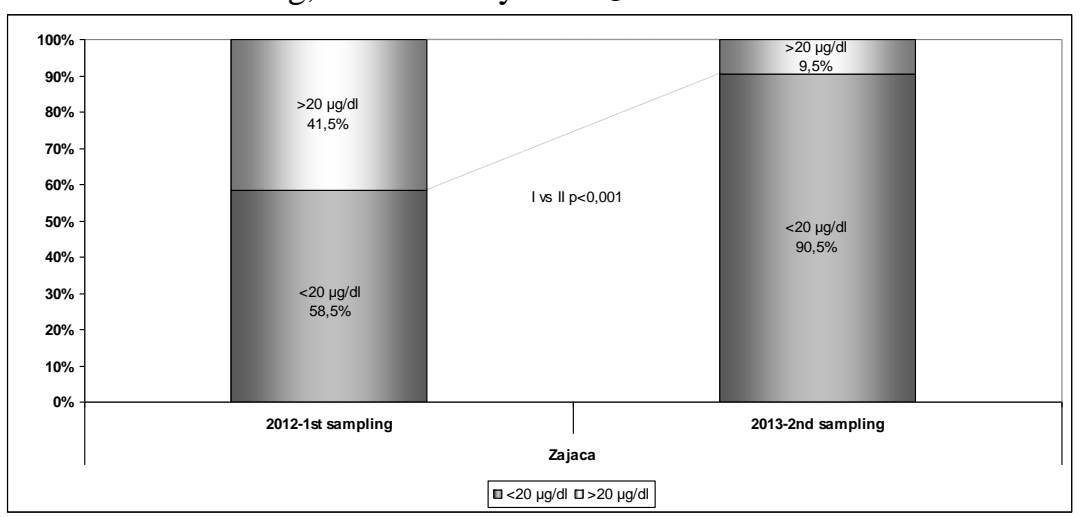

Figure 4 - A comparison between BLLs values under and above $20 \mu \mathrm{g} / \mathrm{dl}$ in samples from 2012/2013

In interpreting the term "distance from the plant to home address", by using data from the questionnaire distributed to the individuals, it means: those living at the distance less than $1 \mathrm{~km}$, from 1.0 to $2.0 \mathrm{~km}, 2.0$ to

Table 3. Groups by home address distance from the plant and BLLs in in both blood sampling episodes

\begin{tabular}{|c|c|c|c|c|c|c|c|c|c|}
\hline \multicolumn{6}{|c|}{ BLL in $1^{\text {st }}$ test $(\mu \mathrm{g} / \mathrm{dl})$} & \multicolumn{4}{|c|}{ BLL in $2^{\text {nd }}$ test $(\mu \mathrm{g} / \mathrm{dl})$} \\
\hline \multirow[t]{2}{*}{$\begin{array}{l}\text { Groups by home } \\
\text { address }\end{array}$} & $\begin{array}{l}\text { Distance }(\mathrm{km}) \\
\text { home to plant }\end{array}$ & $\mathrm{N}$ & Mean & SD & sig & $\mathrm{N}$ & Mean & SD & sig \\
\hline & $<1$ & 46 & 18.98 & 6.06 & \multirow{4}{*}{0.001} & 63 & 12.21 & 6.41 & \multirow{4}{*}{0.01} \\
\hline \multirow{4}{*}{ Exposed } & $1.1-2.0$ & 6 & 13.77 & 4.94 & & 9 & 7.53 & 4.85 & \\
\hline & $2.1-3$ & 1 & 14.01 & & & 2 & 8.30 & 2.79 & \\
\hline & Total & 53 & 18.30 & 6.10 & & 74 & 11.54 & 6.34 & \\
\hline & $1.1-2.0$ & 0 & \multicolumn{2}{|l|}{ none } & \multirow{4}{*}{ ns } & 2 & 6.31 & 1.24 & \multirow{4}{*}{0.03} \\
\hline \multirow{3}{*}{ Partially exposed } & $2.1-3.0$ & 17 & 10.53 & 4.72 & & 26 & 4.70 & 2.67 & \\
\hline & $>3.0$ & 5 & 8.30 & 1.51 & & 0 & 5.85 & 4.39 & \\
\hline & Total & 22 & 10.02 & 4.28 & & 38 & 5.09 & 3.14 & \\
\hline \multirow[t]{2}{*}{ Non-exposed } & $2.1-3.0$ & \multirow{2}{*}{\multicolumn{3}{|c|}{ none }} & \multirow{2}{*}{ none } & 14 & 5.97 & 1.71 & \multirow{2}{*}{ ns } \\
\hline & Total & & & & & 14 & 5.97 & 1.71 & \\
\hline
\end{tabular}

A statistically significant difference is proven for the BLLs in two sampling series, when related to the distance of the home address to the smelting plant. In
$3.0 \mathrm{~km}$ and further than $3 \mathrm{~km}$, from the battery recycling plant in Zajača. Table 3 shows mean blood lead values in two sampling episodes in relation to the distance from home address to the plant.

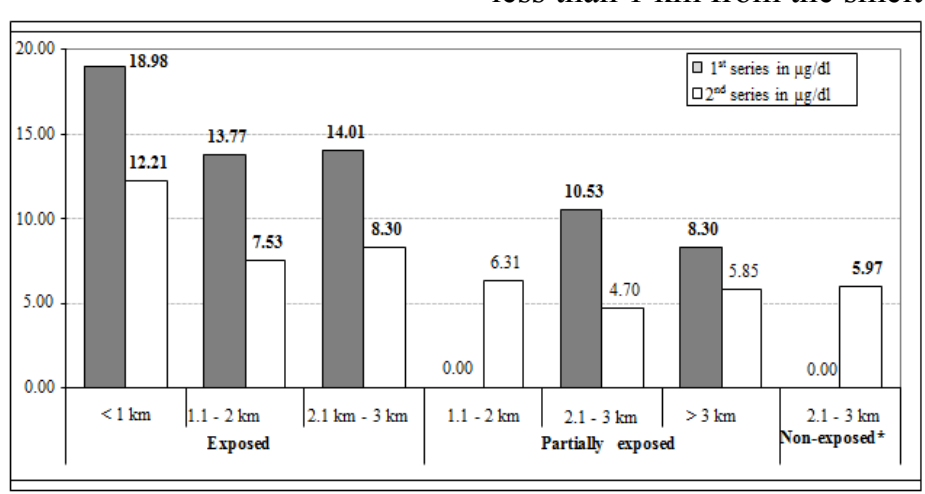

Figure 5 - Distribution of distance from the smelter and intervals of BLLs in children 


\section{DISCUSSION}

The baseline value of blood lead concentration has been widely reported as being between 4 and $6 \mu \mathrm{g} / \mathrm{dl}$. WHO recommends that $98 \%$ of a population examined should have values below $20 \mu \mathrm{g} / \mathrm{dl}$, and $50 \%$ below $10 \mu \mathrm{g} / \mathrm{dl}$ [7]. In the first sampling series of this study $58.5 \%$ of children had BLLs $<20 \mu \mathrm{g} / \mathrm{dl}$, while in $94.3 \%$ of them BLLs were above $10 \mu \mathrm{g} / \mathrm{dl}$, while in the second testing procedure $90.5 \%$ of children had BLLs $<20 \mu \mathrm{g} / \mathrm{dl}$, while in $55.4 \%$ of them BLLs were above $10 \mu \mathrm{g} / \mathrm{dl}$ (Table 2).

In the study conducted in Bulgaria $85 \%$ of exposed children had BLLs beyond $15 \mu \mathrm{g} / \mathrm{dl}$, among which $62 \%$ were higher than $20 \mu \mathrm{g} / \mathrm{dl}$ [15]. Garcia Vargas in Mexico has grouped children according to the distance of their school from the primary lead smelter [16]. In those studying in the school closest to the plant $(650 \mathrm{~m})$
92.8\% had BLLs above $15 \mu \mathrm{g} / \mathrm{dl}$, while only $6.8 \%$ of the control population (school $8100 \mathrm{~m}$ away) had such BLLs. In all 3 studies exposure of the defined population could be analyzed taking the distance from the point source of $\mathrm{Pb}$ emissions from the children's homes and schools as a key parameter.

Concerning this prevalence study, the resulting statistical significance in cases of children exposed to lead, is in accordance with similar prevalence studies, which aimed to prove that environmentally present lead is related to the level of blood lead concentration of the exposed children, whatever was the source of industrial pollution. [14-16, 26-29].

The point sources of pollution were lead ore smelters, battery recycling plants (active ore closed), closed lead mines. Results of those studies are shown in Table 4.

Table 4. Review of similar studies on children living in the vicinity of lead pollution point sources

\begin{tabular}{|c|c|c|c|c|c|}
\hline Town, region, country & $\begin{array}{l}\text { Point source of lead } \\
\text { pollution }\end{array}$ & $\begin{array}{l}\text { Study } \\
\text { year }\end{array}$ & $\begin{array}{l}\text { Distance from } \\
\text { the facility }\end{array}$ & $\begin{array}{l}\text { Mean BLLs } \\
(\mu \mathrm{g} / \mathrm{dl})\end{array}$ & References \\
\hline Santo Amaro, Brazil & Active $\mathrm{Pb}$ smelter & 1992 & $\begin{array}{l}300 \mathrm{~m} \\
900 \mathrm{~m} \\
\end{array}$ & $\begin{array}{l}87.00 \\
58.90 \\
\end{array}$ & $\begin{array}{l}\text { Silvany-Neto et al, } 1996 \\
{[23]}\end{array}$ \\
\hline $\begin{array}{l}\text { Ribeira River Valley, } \\
\text { Sao Paolo, Brazil }\end{array}$ & Smelter, closed in 1995 & 2001 & $\begin{array}{l}\text { exposed } \\
\text { non-exposed }\end{array}$ & $\begin{array}{r}11.25 \\
4.40 \\
\end{array}$ & Paliello et al., 2002 [24] \\
\hline Berat, Albania & Secondary $\mathrm{Pb}$ smelter & 1997 & $\begin{array}{l}<2 \mathrm{~km} \\
>2 \mathrm{~km}\end{array}$ & $\begin{array}{l}43.40 \\
15.00 \\
\end{array}$ & Tabaku et al., 1998 [25] \\
\hline Lavrion, Greece & Active $\mathrm{Pb}$ smelter & 1988 & live close & 21.70 & Maravelias et al., [14] \\
\hline \multirow[t]{2}{*}{ Bulgaria } & \multirow[t]{2}{*}{ Closed lead smelter } & \multirow[t]{2}{*}{2002} & $\begin{array}{l}4 \mathrm{~km} \mathrm{NW} \\
6 \mathrm{~km} \mathrm{~W} \\
\end{array}$ & $24 \pm 9.6$ & \multirow[t]{2}{*}{ Fischer et. al., 2003 [15] } \\
\hline & & & $14 \mathrm{~km} \mathrm{SE}$ & $14.9 \pm 5.7$ & \\
\hline Lagunera, Mexico & Active $\mathrm{Pb}$ smelter & 2000 & $\begin{array}{l}650 \mathrm{~m} \\
1750 \mathrm{~m} \\
8100 \mathrm{~m} \\
\end{array}$ & $\begin{array}{l}27.6 \\
21.8 \\
7.8 \\
\end{array}$ & $\begin{array}{l}\text { Vargas G. et al.,2001 } \\
{[16]}\end{array}$ \\
\hline Managua, Nicaragua & Battery recycling plant & 1998 & $\begin{array}{l}\text { live close } \\
\text { control }\end{array}$ & $\begin{array}{l}17.20 \\
7.40 \\
\end{array}$ & Bonilla et al., 1998 [26] \\
\hline Zajača,Serbia & Secondary $\mathrm{Pb}$ smelter & $\begin{array}{l}1998 / \\
1999\end{array}$ & $\begin{array}{l}\text { exposed } \\
\text { control }\end{array}$ & $\begin{array}{l}15.81 \\
7.36\end{array}$ & Matic et al., 2007 [20] \\
\hline
\end{tabular}

Among mentioned studies reasearching childhood environmental exposure to lead from a point source, it is important to point out the study of Paliello et al., as it deals with a closed down facility [23]. Actually, study was implemented 6 years upon the terminal closure of the lead mine and a primary smelter, in the Ribiera River Valley, Sao Paolo, Brazil, aiming to prove that a heavilly contaminated environment poses a public health risk for children, in continuum, despite the lack of any further industrial pollution caused by production.

Results of this and similar other studies indicate the fact that closing down of the facility, being responsible for major emission to all environmental media, is not, per se, a solution which will ensure safe conditions for healthy growth of children living in its vicinity. Real improvement of children's health could be registred some time after undertaking thorough remediation activities of the terrain, and actions for elimeination of long lasting precipitation of home and ambient dust, rich in lead [27].

Garcia-Vargas defined children's exposure to lead taking into account data on how far is a primary lead smelter in Lagunera, Mexico from primary schools attended by children i.e. $650 \mathrm{~m}, 1750 \mathrm{~m}$ and $8.100 \mathrm{~m} \mathrm{[16].}$

On the other hand, although school attending was not a key issue when forming reasearch groups, 
it's worth mentioning that there is only one primary school in Zajača attended by all children, which could also count as a facilitating factor in the interpretation of percentual coverage of children with $\mathrm{PbB}>10 \mu \mathrm{g} / \mathrm{dl}$. It is good to know that school is located directly accross the street from the plant.

From the examples given in the table above, it is obvious that most of them are in either neighbouring countries or ones near by (Albania, Bulgaria, Greece). The reason for it lays in the fact that most of major studies in the past, of great importance for further break through in development of preventive actions in this field, were undertaken in the regions whose cultural, economic and political bacground highly differs from conditions in the SEE (South East Europe) region, such as USA, Canada, Sweden [27, 28, 29].

In the case of Zajača, a decrease of mean BLLs is evident in the second sampling. Reasons for that we found in the following: a well conducted awareness raising campaign has been undertaken on the field by the staff of the Primary Health Care unit in nearby town Loznica, containing information on the harmfulness of lead in the environment, its pollution, and how to prevent any contact with the metal particles. During the field work, special attention was taken on the issue of personal and home hygiene practice, targeting mothers of exposed children, also being responsible for home cleaning and food preparation. It had a particular importance, due to the fact that vegetables were mostly grown in home garden plots, and watered with water from a heavily contaminated underground source. According to Brown et al., strict enforcement of lead poisoning prevention statutes is an effective primary prevention strategy, especially in conducting housing policies in homes of children exposed continuously to a registered pollution source [30].

The other important reason for the decrease of BLLs in the samples taken in 2013 was a long lasting strike of the plant workers, which put the plant into a standstill. A conclusion that disruption of production cycle in the lead smelter could have an impact on a decrease in blood lead concentration was mentioned in a study in Veles, FRY Macedonia, in which, both ambient air pollution and BLLs of exposed children were measured in the period of a full-blown plant's production capacity, and when it stopped working [31].

A significant statistical difference was noted between BLLs in school children during a full capacity lead smelting process, and those taken when production stopped. Samples taken in June 2003 had a mean BLL of $16.51 \mu \mathrm{g} / \mathrm{dl}$, while during the plant's lead production break in 2004, BLLs of exposed children have dropped significantly, to $7.64 \mu \mathrm{g} / \mathrm{dl}$.
Mean BLLs in children from Gornja Borina, accounted as non-exposed ones, is yet not as low as expected (5.97 $\mu \mathrm{g} / \mathrm{dl} ;$ SD 1.71), although they live up hill at the spot higher than the point of emission from the plant's chimney stack. One of the reasons for this is that they all attend school in Zajača, located just across the street from the smelter. According to researchers, even children with safe BLLs $(<10 \mu \mathrm{g} / \mathrm{dl})$ had significant brain damage [32]. This means that even children that were identified as a risk-free population group are exposed to serious public health risk, and should be treated the same way as children from other two examined groups.

\section{CONCLUSIONS}

This study has confirmed differences in lead exposure in the various subgroups residing at different distances from, or attending school close to a point source of lead pollution. Also, significant statistical difference among BLLs from samples taken in two test series, with the implementation of public health measures in children's home environment in between the samplings, gives hope that any such further actions, together with remediation measures of the terrain could result in even more reduced BLLs, giving these children better chances for their personal development.

\section{ACKNOWLEDGMENTS}

The authors highly appreciate the willingness of the Ministry of Health of Serbia to understand the plight of parents of exposed children and to allocate resources for the processes of blood sampling and analyses on the content of lead in during 2012-2013. The authors, also, acknowledge the willingness of the COST Action IS1408, Industrially Contaminated Sites and Health Networks, to notify Zajača as an important industrially contaminated hot spot in Serbia.

\section{REFERENCES}

[1] Tong S, von Schirnding YE, Prapamontol T. Environmental lead exposure: a public health problem of global dimensions. Bulletin of the World Health Organization, 78:1068-1077, 2000.

[2] Childhood lead poisoning, World Health Organization, 2010, Geneva, Switzerland, ISBN 978924 $1500333,2010$.

[3] Wasserman Gail A, Xinhua Liu, Lolacono N.J, Factor-Litvak P, Kline J. K, Popovac D, Morina N. Lead exposure and intelligence in 7-year old children. The Yugoslav Prospective Study; Environ Health Perspect, 105:956-962, 1997.

[4] Gomaa A, Hu H, Bellinger D, Schwartz J, GonzalesCossio T. Maternal bone lead as an independent risk 
factor for fetal neurotoxicity: a prospective study, Pediatrics, 110: 1100118, 2002.

[5] Manton WI, Angle CR, Stanek KL, Reese YR, Kuehnemann TJ, Acquisition and retention of lead by young children, Environ Res, (82): 60-80, 2000.

[6] Wilhelm M, Eberwein G, Holzer J, Gladtke D. Human biomonitoring of cadmium and lead exposure of child-mother pairs from Germany living in the vicinity of industrial sources (hotspot study NRW); $J$ Trace Elem Med Biol 19(1): 83-90, 2005.

[7] Moreno Ma.Elena, Leonov C, Acosta-Saavedra, Meza-Figuera D, Ostrovski-Wigman P; Biomonitoring of metal in children living in a mine tailings zone in Southern Mexico: a pilot study. Inter Journal of Hygiene and Environ Health, 213,No4, 252-58, 2010.

[8] Pino P, Walter T, Oyarzun MJ, Burden M J, Lozoff $\mathrm{B}$, Rapid drop in infant blood lead levels during the transition to unleaded gasoline use in Santiago, Chile. Arch Environ Health, 59: 182-87, 2004.

[9] Hilts SR, Bock SE, Oke TL, Yates CL, Copes RA; Effects of interventions on children's blood lead levels, Environ Health Perspect, 106 (2):79 - 83, 1998.

[10]Maravelias C, Hatzakis A, Katsouyani K, Trichopoulos D, Exposure to lead and cadmium of children living near a lead smelter at Lavrion, Greece. Sci Total Environ 84 (1989): 67-70.

[11]Fischer A B, Georgieva R, Nikolova V, Halkova J, Bainova A, Hristeva V, Penkov D, Alandjiisk D, Health risk for children from lead and cadmium near a non-ferrous smelter in Bulgaria. Int J Hyg Environ Health, 252-58, 2013 (2010).

[12]Garcia-Vargas CG, Rubio Andrade M, Del Razo LM, BorjaAburto V, Vera Aguilar E, Cabrian ME. Lead exposure in children living in a smelter community in region Lagunera, Mexico. J Toxicol Environ Health, 62(6): 417-429, 2001.

[13]Mioč UB, Colomban Ph, Sagon G, Stojanović M, Rosić A. Ochre Decor and Cinnabar Residues in Neolithic Pottery from Vinča, Serbia. Journal of Raman Spectroscopy, 35, 843-846, 2004.

[14]Petković S, Traces of Roman Metallurgy in Eastern Serbia; Journal of Mining and Metallurgy 45(2), (): 187-196, 2009.

[15]Jovanović B, Beginning of the Metal Age in the Central Balkans According to the Results of the Archeometallurgy; Journal of Mining and Metallurgy 45(2), B,: 143-147, 2009.
[16]UNEP, Mining and Environment in the Western Balkans, Ed Christina Stuhlberger: 77-82, 2009.

[17]Popović Lj, Antimony in Yugoslavia, Publ. "Zenit", Beograd, (in Serbian), 1995.

[18]Radović N, Kamberović Ž, Parias D, Cleaner metallurgical industry in Serbia: a road to sustainable development. Chemical Industry and Chemical Engineering Quarterly, 15, 1:1-4, 2009.

[19]Kamberović Ž, Korać M, Andjić Z, Štulović M, Kovačević T, Vujović A, Ilić I, Conceptual design for treatment of mining and metallurgical wastewaters which contain arsenic and antimony, Metall.Mater Eng. Vol 18(4), 321-331, 2012.

[20]Matić B., Gojković M., Separović N.; Influence of Lead in Suspended Particles on Blood Lead Levels of Children Living in the Vicinity of a Secondary Lead Smelter. $1^{\text {st }}$ International WeBIOPATR Workshop, Beograd, Serbia, Book of Extended Abstracts, Eds. M.Jovasevic-Stojanovic, A.Bartonova: 124-126, 22 25th May 2007.

[21]Decree on determining of the Programme for the Air Quality Control by the National Network of Measuring Stations, "Official Gazette of the Republic of Serbia”, No. 58/11.

[22]Annual report on the air quality status in Republic of Serbia in 2013; Serbian Agency for Environment Protection, Ministry of energy, development and environment protection (). Available at: www.sepa.gov.rs/download/VAZDUH2013.pdf, 2014.

[23] Silvany-Neto AM, Carvalho FM. Lead poisoning among children of Santo Amaro, Bahia, Brazil in 1980, 1985. and 1992. Bull.Pan Am Health Org; 1996; 30 (1): 51-62.

[24]Paoliello MM, De Capitani EM. Exposure of children to lead and cadmium from a mining area of Brazil; Environ Res; 88 (2): 120-128, 2002.

[25]Tabaku A, Bizgha V, Rahlenbeck S.I. Biological monitoring of lead exposure in high risk groups in Berat, Albania. J Epidemiol Community Health; 52: 234-236, 1998.

[26]Morales Bonilla C. A community-initiated study of blood lead levels of Nicaraguan children living next to a battery factory. Am J Public Health, 88 (2): 1843 45, 1998.

[27]Kimbrough R, Maurice LeVois. Survey of lead exposure around a closed lead smelter. Pediatrics; 95 (4): 550-554, 1995. 
[28]Stromberg U, Lundh T, Schutz A. Yearly measurements of blood lead in Swedish children since 1978: an update focusing on the lead-free petrol period 1995-2001. Occup Environ Med; 60: 370372, 2003.

[29]Wohl A.R, Dominguez A. Evaluation of Lead Levels in Children Living near a Los Angeles Conty Battery Recycling Facility; Environ Health Perspect 104 (3):314-317, 1996.

[30]Brown MJ, Gardner J, Sargent JD, Swartz K, Hu H, Timperi R. The Effectiveness of Housing Policies in Reducing Children's Lead Exposure, Am J Public Health. 91:621-626, 2001.
[31]Kochubovski M. Blood-Lead Levels in Schoolchildren from Veles, Related to the Ambient Air ollution by Lead; Proceedings of the NATO Advanced Study Institute on Exposure and Risk Assessment of hemical Pollution Contemporary Methodology, Sofia, Bulgaria; Springer, ISBN 978-90-4812335-3, 009: 371-378.

[32]Levei M. Phasing out Lead from Gasoline; Worldwide Experience Policy Implementations, Environment Department, The World Bank, Washington, WB Technical Paper No.397, 1998.

\section{REZIME}

\section{KONCENTRACIJA OLOVA U KRVI KOD DECE KOJA ŽIVE U BLIZINI TOPIONICE OLOVA I RUDNIKA ANTIMONA U SRBIJI}

Cilj ove studije preseka je da utvrdi koncentraciju olova u krvi kod dece, koja žive u blizini rudnika antimona i topionice olova u Zajači. Ostali ciljevi bili su uspostavljanje korelacije između koncentracije olova u krvi (BLLs) i stepena izloženosti dece (izložena, delimično izložena i neizložena, kao i da uporedi vrednosti BLLs iz dve uzastopne serije uzimanja uzoraka krvi na analizu, 2012. i 2013. godine. Kao laboratorijska analiza korišćena je atomska apsorpciona spektrometrija (AAS). Statistička značajnost povezanosti testirana je univarijantnim metodama, i neparametrijskm testovima za atributivne varijable: Hi-kvadrat test, test proporcije. U slučaju neparametrijskih varijabli, korišćeni su sledeći testovid: Kolmogorov-Smirnov Z test za testiranje normalnosti raspodele; ANOVA za normalnu raspodelu, dok je Kruskal Wallis Test korišćen u slučajevima nepostojanja normalne raspodele. Uzeto je 142 uzoraka krvi za ispitivanje na prisustvo olova, $i$ to od dece koja su izložena, delimično izložena i neizložena. $U$ slučaju dece koja žive na rastojanju manjem od $1 \mathrm{~km}$ od topionice, srednja vrednost BLLs je $18.98 \mu \mathrm{g} / \mathrm{dl}$ u prvoj seriji ispitivanja, i $12.21 \mu \mathrm{g} / \mathrm{dl}$, u drugoj seriji. Kod dece koja žive na razdaljini većoj od $3 \mathrm{~km}$, srednja vrednost BLLs je na prvom uzorkovanju bila $8.30 \mu \mathrm{g} / \mathrm{dl}$, dok je u drugoj iznosila $5.85 \mu \mathrm{g} / \mathrm{dl}$ ). $U$ obe serije, koncentracije olova u krvi dece iz Zajača bile su najviše.

Klučne reči: olovo u krvi, deca izložena olovu, topionica olova 